\title{
Bats use live fences to move between tropical dry forest remnants
}

\author{
José G. Martínez-Fonseca ${ }^{1}$ (I) ｜ Marlon Chávez-Velásquez ${ }^{1}$ | Kimberly Williams-Guillen ${ }^{2,3}$ | \\ Carol L. Chambers ${ }^{1}$
}

${ }^{1}$ School of Forestry, Northern Arizona University, Flagstaff, AZ, USA

${ }^{2}$ School of Environment and Sustainability, University of Michigan, Ann Arbor, MI, USA

${ }^{3}$ Paso Pacifico, Ventura, CA, USA

\section{Correspondence}

José G. Martínez-Fonseca, School of Forestry, Northern Arizona University, 200 E Pine Knoll Dr, Flagstaff, AZ 86011, USA. Email:jm3934@nau.edu

Associate Editor: Jennifer Powers Handling Editor: Tomás Carlo

\author{
Abstract \\ Linear features can benefit wildlife by assisting animal movement. We captured bats \\ along barbed-wire and live-tree fences connecting tropical dry forest patches in \\ Nicaragua. Bat species richness and captures were higher along live fences but we \\ noted differences in sex ratios, richness, and species composition compared to sur- \\ rounding natural forests. \\ Abstract in Spanish is available with online only \\ KEYWORDS \\ Chiroptera, connectivity, forest patches, hedgerow, Lophostoma brasiliensis, Phyllostomidae
}

\section{1 | INTRODUCTION}

FRAGMENTATION AND LOSS OF HABITAT NEGATIVELY AFFECT ANIMAL POPULATIONS BY LIMITING access to resources, restricting demographic exchange, and impeding gene flow (Cosgrove, McWhorter, \& Maron, 2018; Fahrig \& Merriam, 1985; Hanski, 1991). Species have unique behavioral or morphological adaptations that influence their habitat requirements and affect dispersal through non-optimal environments (Bonaccorso, 1979; Cisneros, Fagan, \& Willig, 2015a; Fenton et al., 1992; Fleming, 1982; Meyer \& Kalko, 2008). In fragmented forests, even small clearings can have a negative impact on many species, restricting movement across landscapes (Bierregaard, Lovejoy, Kapos, Dos Santos, \& Hutchings, 1993; Davies, Margules, \& Lawrence, 2000; Entwistle et al., 2001; Powell \& Powell, 1987; Saunders \& Ribeira, 1991). However, tree and fence lines, as linear landscape features, can be used as "spatial references" by bats to commute between roosts and feeding sites (Entwistle et al., 2001; Schaub \& Schnitzler, 2007; Schnitzler, Moss, \& Denzinger, 2003; Verboom \& Huitema, 1997). Bat use of fences and hedgerows was described in Europe in mixed farmlands (e.g., Downs \& Racey, 2006; Lacoeuilhe, Machon, Julien, \& Kerbiriou, 2016; Toffoli, 2016). In Europe, the beneficial effects of linear structures on open landscape matrices are recognized and recommended for bat conservation (Entwistle et al., 2001).
In Latin America, standard fences typically consist of 3 to 6 lines of barbed wire supported by wooden posts spaced every 3 to $4 \mathrm{~m}$. In Nicaragua, a single row of fast growing trees (e.g., Gliricidia sepium and Bursera simaruba), spaced 1.5 to $4 \mathrm{~m}$ apart, often replaces posts as a common configuration for live fences (Albrecht \& Kandji, 2003; Sauer, 1979; J. Martínez-Fonseca, pers. obs.). Some landowners prefer live fences because they provide a practical and permanent delimitation for properties, lower maintenance cost (live trees need less frequent replacement), shade and forage for livestock, and, eventually, production of fruit, firewood, and timber (Beer, 1987; Lagemann \& Heuveldop, 1983; Sauer, 1979). Nevertheless, landowners recognize constraints to the establishment of live fences, making them less common than producers would desire in Nicaragua's southwestern tropical dry forest landscape (e.g., increased time and effort to establish; Dorgay, Muelle, \& Klooster, 2016).

In the Neotropics, the use of fence lines by bats remains undocumented in many biomes. The ability of bats to use live fences and hedgerows was reported in Mexico in tropical rain forest (Estrada \& Coates-Estrada, 2001; Estrada, Coates-Estrada, \& Meritt, 1993) and tropical moist forest in Nicaragua (Medina, Harvey, Merlo, Vilchez, \& Hernandez, 2007), although none of these studies explicitly compared live fences with standard fences. 
Nicaragua is a world biodiversity hot spot for bats (Hutson, Mickleburgh, \& Racey, 2001) with 108 species of bats representing nine families (Medina-Fitoria, 2014; Medina-Fitoria et al., 2015; Reid, 2009). Three species are categorized as near threatened under the International Union for Conservation of Nature and Natural Resources (IUCN) because of habitat loss and fragmentation (Aguirre, Mantilla, Miller, \& Dávalos, 2008; Miller \& Medina, 2008; Rodriguez \& Pineda, 2015). This area also supports tropical dry forest (TDF), one of the most threatened forest types in the tropics (Janzen, 1988; Miles et al., 2006).

High diversity and habitat loss of TDF accentuate the role of this region of Nicaragua for bat conservation. We selected an area with mixed human use in a populated region of Nicaragua that included farming, livestock ranching, and fragmented TDF. Based on the activity of bats along live fences and hedgerows documented by other studies, we expected more bats and species to select live over standard fences. Our objective was to compare bat activity and diversity between live and standard fences simultaneously, and explicitly evaluate the utility of live fences as corridors for bats in this altered landscape.

\section{2 | METHODS}

Our study area encompassed the Rivas Isthmus $\left(11^{\circ} 12^{\prime} 33^{\prime \prime} \mathrm{N}\right.$, $85^{\circ} 44^{\prime} 2^{\prime \prime} \mathrm{W}$ ), in southwestern Nicaragua, located between Lake Nicaragua and the Pacific Ocean (Figure S1), in forest recognized as TDF (Holdridge, 1967). At least 63 bat species occur in this area (Medina-Fitoria, 2014). Annual air temperature averaged $26.7^{\circ} \mathrm{C}$ with annual precipitation of 1400-2000 mm; a well-defined dry season occurs from December to April (Sesnie, Hagell, Otterstrom, Chambers, \& Dickson, 2008).

We selected sites using four criteria: (a) the presence of two fences, one live and one standard, where each connected forest patches across open pastures or agricultural fields, (b) the pair of fences were $\leq 100 \mathrm{~m}$ apart to allow bats to be simultaneously monitored at both localities (Figure S2), (c) no other flyways, evident landforms or structures (e.g., creeks, buildings) intersected the fences across open areas, and (d) average distance between sites was $>10 \mathrm{~km}$. We sampled from 29 May to 7 August 2015 .

To capture bats, we used single mist nets $(2.6 \mathrm{~m} \times 6$ to $18 \mathrm{~m}$ for bats, 38 mm mesh, Avinet, Inc., New York, USA; Kunz \& Kurta, 1988) placed in similar configurations to maximize captures along both fence types. We opened nets simultaneously at dusk $(\sim 1,800 \mathrm{hr}$ ) for up to four hours per site ( $\geq 40$ net h per site [one net $\mathrm{h}=$ one 6-m net open for one $\mathrm{h}]$, range $40-115$ net $\mathrm{h}$, mean and SE: $63.5 \pm 3.6$ net $\mathrm{h}$ )

Animals were captured under Nicaraguan Permit No. 015122011, with the approval of the Northern Arizona University Institutional Animal Care and Use Committee (15-006) and following the guidelines of the American Society of Mammalogists (Sikes, 2016). For species identification, we recorded morphometrical data and sex; nomenclature was adopted from Reid (2009) and MedinaFitoria (2014).

We estimated species richness with EstimateS (Version 9.1.0, Colwell, 2013) using the abundance-based coverage estimator (ACE; Chao, Hwang, Chen, \& Kuo, 2000; Chao \& Lee, 1992; Chazdon, Colwell, Denslow, \& Guariguata, 1998). We used these estimates to compare species richness between live and standard fences.

We modeled capture rate of bats using a generalized linear mixed model framework with a negative binomial (to test for overdispersion) or Poisson distribution and a logit link function (SAS 9.4 PROC GLIMMIX; SAS Institute, Cary, NC 2019). We assigned site as a random effect and adjusted count data for effort using net hours. We compared bat captures by contrasting individual species (if $>50$ individuals) with all other species combined (those with $\leq 50$ individuals per species). We tested for effect of fence (live, standard), sex (female, male), moon phase (percent illumination since some bats are lunophobic and sampling nights were distributed across all lunar phases; e.g., Morrison, 1978; Thies, Kalko, \& Schnitzler, 2006), and interactions for species, sex, and fence type. Because we did not observe overdispersion, we reported results using a Poisson distribution and applied the Laplace approximation for parameter estimation. We modeled species richness using the same procedures; however, we used only fence type and moon phase as parameters in the model. We set $\alpha$ at 0.05 .

\section{3 | RESULTS}

We found 27 sites that met our sampling criteria with a mean distance $( \pm S D)$ of $13.0 \pm 0.3 \mathrm{~km}$ between sites. We captured 279 individuals (225 along live fences and 54 along standard fences) during 1714 net hours (equally divided between live and standard fences). Bats represented 17 species, 11 genera, and four families (Table 1). Two species, Artibeus jamaicensis $(n=147)$ and Carollia perspicillata $(n=58$ ), accounted for $73 \%$ of captures. We captured 15 and eight species along live and standard fences, respectively (Table 1). Per site, number of bats captured averaged $8.3 \pm 0.9$ for live and $2.0 \pm 0.4$ for standard fences. Predicted species richness was higher for live $(n=24)$ compared to standard fences ( $n=10$; Figure 1$)$. Estimates of species richness were greater than our actual captures of species (Figure 1).

Species richness was higher for live than standard fences $(d f=1$, $26, F=20.41, p=.0001$ ). We did not detect an effect of moon phase on richness $(d f=1,26, F=3.88, p=.06)$. We found that the relative number of males and females captured depended on species $(d f=2$, $286, F=3.74, p=.02$ ) and captures by fence type also varied across species $(d f=2,286, F=3.64, p=.03$ ). Males dominated captures overall, although their representation varied across species (e.g., Carollia perspicillata; Table 1). Live fences benefitted some species (e.g., Artibeus jamaicensis) more than others (Table 1). We did not detect an effect of moon phase ( $d f=1,286, F=2.83, p=.09$ ), fence*$\operatorname{sex}(d f=1,286, F=0.02, p=.89)$, or fence*sex*species $(d f=2,286$, $F=2.45, p=.09)$ 
TABLE 1 Number of bats by sex ( $F=$ female and $M=$ male) and species captured at sites with live (Live) and standard (Standard) fences between May and August 2015, Rivas, Nicaragua. The number of sites (\# of sites) represents the number of unique locations surveyed where the species was captured

\begin{tabular}{|c|c|c|c|c|c|c|c|}
\hline \multirow[b]{2}{*}{ Family } & \multirow[b]{2}{*}{ Species } & \multirow[b]{2}{*}{ \# of sites } & \multicolumn{2}{|c|}{ Standard } & \multicolumn{2}{|c|}{ Live } & \multirow[b]{2}{*}{ Total bats } \\
\hline & & & $\mathbf{F}$ & $M$ & $\mathbf{F}$ & M & \\
\hline \multirow[t]{8}{*}{ Phyllostomidae } & Artibeus jamaicensis $^{a}$ & 26 & 3 & 18 & 40 & 84 & 147 \\
\hline & Carollia perspicillata & 22 & 9 & 6 & 16 & 27 & 58 \\
\hline & Sturnira parvidens & 10 & 2 & 3 & 5 & 8 & 18 \\
\hline & Desmodus rotundus & 5 & 2 & 4 & 1 & 4 & 11 \\
\hline & Artibeus lituratus & 7 & 0 & 2 & 1 & 7 & 10 \\
\hline & Carollia subrufa & 5 & 0 & 0 & 3 & 3 & 6 \\
\hline & Dermanura watsoni & 3 & 0 & 0 & 0 & 3 & 3 \\
\hline & Lophotostoma brasilienis & 1 & 0 & 0 & 0 & 1 & 1 \\
\hline \multirow[t]{2}{*}{ Mormopidae } & Pteronotus mesoamericanus & 1 & 1 & 0 & 0 & 0 & 1 \\
\hline & Pteronotus personatus & 1 & 0 & 0 & 0 & 1 & 1 \\
\hline Noctilionidae & Noctilio albiventris & 1 & 0 & 1 & 0 & 0 & 1 \\
\hline \multirow[t]{2}{*}{ Vespertilionidae } & Myotis nigricans & 2 & 0 & 0 & 1 & 1 & 2 \\
\hline & Eptesicus furinalis & 1 & 0 & 0 & 0 & 1 & 1 \\
\hline Total number of individuals & & & 19 & 34 & 74 & 150 & 279 \\
\hline Total number of species & & & 6 & 6 & 8 & 15 & 17 \\
\hline
\end{tabular}

${ }^{a}$ Sex for 2 individuals, one from each fence type was not identified, and total count includes those individuals.

FIGURE 1 Estimated species richness $( \pm S D)$ of bats using live and standard fences, May-Aug 2015, Rivas, Nicaragua
Live $\quad$ Standard

30

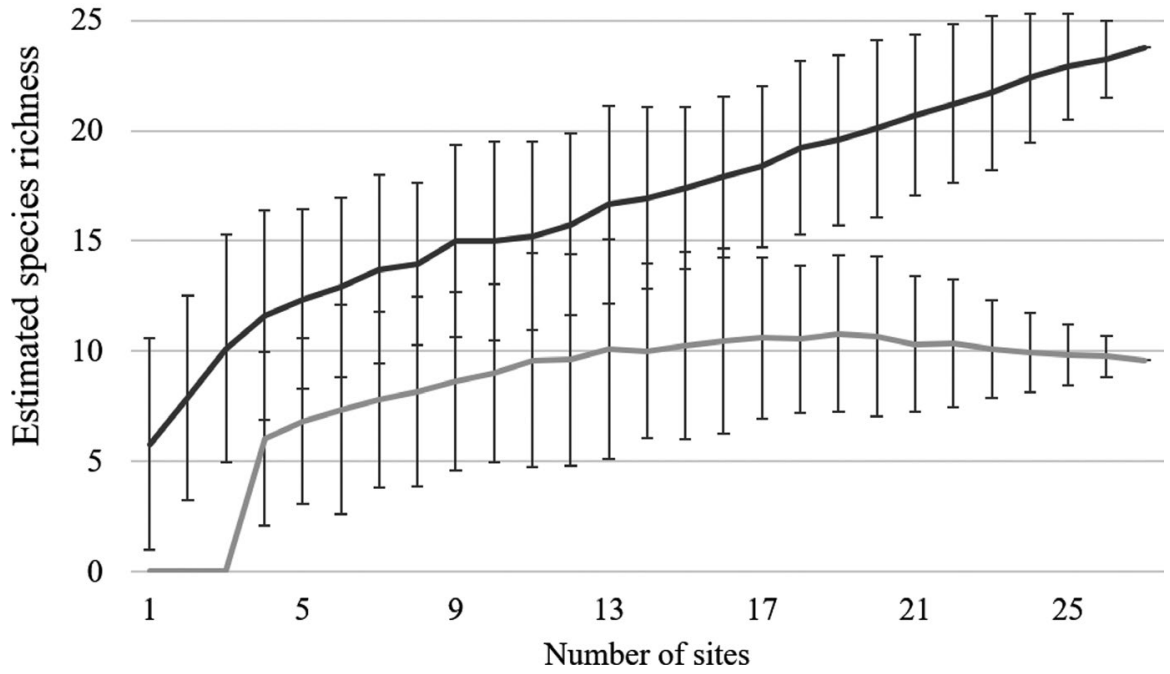

\section{4 | DISCUSSION}

Our results show that use of live fences was four times greater than use of standard fences by bats. In addition, we captured twice as many species along live fences as standard fences; both richness estimates and species accumulation curves suggested our sampling underrepresented the richness of species using live fences. Our findings thus suggest that live fences favorably affect bats in the 
tropical dry forest of Nicaragua. Phyllostomids dominated our captures (97\%); these bats have special echolocation and morphological adaptations to fly in cluttered environments (Kalko, 2004; Stockwell, 2001); thus, live fences may offer a familiar environment for leafnosed bats to move across disturbed areas. The most common Phyllostomids that we captured (Carollia perspicillata and Artibeus jamaicensis) can travel large distances and have low fidelity to local forest patches (Bianconi, Mikich, \& Pedro, 2006; Menezes-Jr et al., 2008; Morrison, 1980) making them more adaptable to altered landscapes. However, C. perspicillata and A. jamaicensis benefitted from live fences. Given the important role of Carollia and Artibeus as seed dispersers of trees, live fences can increase gene flow across forest fragments and increase regeneration in open areas (Fleming, 2004; Hoffmaster, Vonk, \& Mies, 2016).

We captured more males than females along both fence types. This contrasts with concurrent captures in nearby forested riparian sites, where sex ratios were equal ( $n=16$ sites, net $\mathrm{h}=891$, number of females $=480$, number of males $=439, \mathrm{C}$. Chambers, unpubl. data). Sex ratio differences might be influenced by food availability, reproductive condition, or risk aversion (Rocha et al., 2017). Although we did not detect a significant effect of moon phase on captures or richness, we noted a trend toward an effect (more captures and higher richness on less bright nights), consistent with studies suggesting lunophobia in bats is species-specific (Lang, Kalko, Romer, Bockholdt, \& Dechman, 2006; Mello, Kalko, \& Silva, 2013).

Live fences appeared to benefit species moving among forest patches in fragmented landscapes. However, the differences in abundance, species richness, and sex ratios in our captures compared to those found in adjacent mature forests suggest that live fences present constraints to movement and benefit species differently. Protecting natural corridors such as riverbeds and retaining forested strips across the landscape will better enhance survival for forest-associated species (Cisneros, Fagan, \& Willig, 2015b; Herrera, Duncan, Clare, Fenton, \& Simmons, 2018; Naiman, Decamps, \& Pollock, 1993), particularly when coupled with protection of larger forested areas.

Our findings support the use of live fences to improve connectivity between forest patches in other parts of the TDF and likely other forest types in Mesoamerica. Our study also provides the first evidence that live fences are used by bats to move within a fragmented TDF landscape. Although we captured only one gleaning insectivore with specialized feeding habits and associated with less-disturbed forests (male Lophostoma brasiliensis; Bonaccorso, 1979; Fleming, 1982), it used a live fence. Chambers, Cushman, Medina-Fitoria, Martínez-Fonseca, and Chávez-Velásquez (2016) found that L. brasiliensis was one of the most common Phyllostomine species in our study area, suggesting that some forest-associated bats might also benefit from live fences.

Future studies could use acoustic monitoring to assess selection of live fences by other bat families that are seldom caught in mist nets (Rodhouse, Vierling, \& Irvine, 2011; Wilson, Cole, Nichols, Rudran, \& Foster, M., 1996) and consider the effects of structural differences of live fences (e.g., density, height, and age of trees) on bats. Given the ecological importance of bats as pollinators, seed dispersers, and predators, we recommend that local entities support landowners in maintaining existing live fences and increasing their presence when possible in TDF in Latin America.

\section{ACKNOWLEDGMENTS}

We thank Luis Gutierrez-López, Christian Bonilla, and Maynor Fernández-Mena for field assistance, Paso Pacífico for logistical support during data collection, and Roy St. Laurent for statistical consulting. We thank Subject Editor Tomas Carlo, Tad C. Theimer, and two anonymous reviewers for comments that substantially improved the manuscript.

\section{DATA AVAILABILITY STATEMENT}

Data available from the Dryad Digital Repository: https://doi. org/10.5061/dryad.44jOzpc99(Martínez-Fonseca,Chávez-Velásquez, Williams-Guillen, \& Chambers., 2019).

\section{ORCID}

José G. Martínez-Fonseca iD https://orcid.

org/0000-0002-3181-2525

\section{REFERENCES}

Aguirre, L., Mantilla, H., Miller, B., \& Dávalos, L. (2008). Vampyrum spectrum. The IUCN Red List of Threatened Species 2008: e.T22843A9395576. Retrieved from: http://dx.doi.org/10.2305/ IUCN.UK.2008.RLTS.T22843A9395576.en

Albrecht, A., \& Kandji, S. T. (2003). Carbon sequestration in tropical agroforestry systems. Agriculture. Ecosystems and Environment, 99, 15-27. https://doi.org/10.1016/s0167-8809(03)00138-5

Beer, J. (1987). Experiences with fence line fodder trees in Costa Rica and Nicaragua. In J. Beer, H. W. Fassbender, \& J. Hueveldop (Eds.), Advances in agroforestry research (pp. 215-222). San José, Costa Rica: CATIE.

Bianconi, G. V., Mikich, S. B., \& Pedro, W. A. (2006). Movements of bats (Mammalia, Chiroptera) in Atlantic Forest remnants in southern Brazil. Revista Brasileira De Zoologia, 23, 1199-1206. https://doi. org/10.1590/s0101-81752006000400030

Bierregaard, R. O., Lovejoy, T. E., Kapos, V., Dos Santos, A., \& Hutchings, R. W. (1993). The biological dynamics of tropical rainforest fragments. BioScience, 42, 859-866. https://doi.org/10.2307/1312085

Bonaccorso, F. J. (1979). Foraging and reproductive ecology in a Panamanian bat community. Bulletin of the Florida State Museum, 24 , 359-408.

Chambers, C. L., Cushman, S. A., Medina-Fitoria, A., Martínez-Fonseca, J., \& Chávez-Velásquez, M. (2016). Influences of scale on bat habitat relationships in a forested landscape in Nicaragua. Landscape Ecology, 31, 1299-1318. https://doi.org/10.1007/s10980-016-0343-4

Chao, A., Hwang, W. H., Chen, Y. C., \& Kuo, C. Y. (2000). Estimating the number of shared species in two communities. Statistica Sinica, 10, 227-246.

Chao, A., \& Lee, S. M. (1992). Estimating the number of classes via sample coverage. Journal of the American Statistical Association, 87, 210-217. https://doi.org/10.2307/2290471

Chazdon, R. L., Colwell, R. K., Denslow, J. S., \& Guariguata, M. R. (1998). Statistical methods for estimating species richness of woody regeneration in primary and secondary rain forests of $\mathrm{NE}$ Costa Rica. In I. F. Dallmeier, \& J. A. Comiskey (Eds.), Forest biodiversity research, monitoring and modeling: Conceptual background and Old-World case studies (pp. 285-309). Paris, France: Parthenon Publishing. 
Cisneros, L. M., Fagan, M. E., \& Willig, M. R. (2015a). Season-specific and guild-specific effects of anthropogenic landscape modification on metacommunity structure of tropical bats. Journal of Animal Ecology, 84, 373-385. https://doi.org/10.1111/1365-2656.12299

Cisneros, L. M., Fagan, M. E., \& Willig, M. R. (2015b). Effects of human-modified landscapes on taxonomic, functional and phylogenetic dimensions of bat biodiversity. Diversity and Distributions, 21, 523-533. https://doi.org/10.1111/ddi.12277

Colwell, R. K. (2013). EstimateS: Statistical estimation of species richness and shared species from samples. Version 9. User's Guide and application retrieved from http://purl.oclc.org/estimates.

Cosgrove, A. J., McWhorter, T. J., \& Maron, M. (2018). Consequences of impediments to animal movements at different scales: A conceptual framework and review. Diversity and Distributions, 24, 448-459. https ://doi.org/10.1111/ddi.12699

Davies, K. F., Margules, C. R., \& Lawrence, J. F. (2000). Which traits of species predict population declines in experimental forest fragments? Ecology, 81, 1450-1461. https://doi.org/10.2307/177221

Dorgay, E., Muelle, R., \& Klooster, A. (2016). Exploring possibilities for reforestation in Southwestern Nicaragua: The social and ecological dimensions of living fence rows. (M.S. Thesis). University of Michigan. Ann Arbor, USA.

Downs, C. N., \& Racey, P. A. (2006). The use by bats of habitat features in mixed farmland in Scotland. Acta Chiropterologica, 8, 169-185. https ://doi.org/10.3161/1733-5329(2006)8[169:tubboh]2.0.co;2

Entwistle, A. C., Harris, S., Hutson, A. M., Racey, P. A., Walsh, A., Gibson, S. D., ... Johnston, J. (2001). Habitat management for bats: A guide for land managers, land owners and their advisors. Peterborough, UK: Joint Nature Conservation Committee.

Estrada, A., \& Coates-Estrada, R. (2001). Bat species richness in live fences and in corridors of residual rain forest at Los Tuxtlas, Mexico. Ecography, 24, 94-102. https://doi. org/10.1034/j.1600-0587.2001.240111.x

Estrada, A., Coates-Estrada, R., \& Meritt, D. (1993). Bat species richness and abundance in tropical rain forest fragments and in agricultural habitats at Los Tuxtlas, Mexico. Ecography, 16, 309-318. https://doi. org/10.1111/j.1600-0587.1993.tb00220.x

Fahrig, L., \& Merriam, G. (1985). Habitat patch connectivity and population survival. Ecology, 66, 1762-1768. https://doi.org/10.2307/2937372

Fenton, M. B., Acharya, L., Audet, D., Hickey, M. B. C., Merriman, C., Obrist, M. K., ... Adkins, B. (1992). Phyllostomid bats (Chiroptera: Phyllostomidae) as indicators of habitat disruption in the Neotropics. Biotropica, 24, 440-446. https://doi.org/10.2307/2388615

Fleming, T. H. (1982). Foraging strategies of plant-visiting bats. In T. H. Kunz (Ed.), Ecology of bats (pp. 287-325). Boston, MA: Springer.

Fleming, T. H. (2004). Dispersal ecology of neotropical Piper shrubs and treelets. In L. A. Dyer, \& A. N. Palmer (Eds.), Piper: A model genus for studies of phytochemistry, ecology, and evolution (pp. 58-77). New York, NY: Springer.

Hanski, I. (1991). Single-species metapopulation dynamics: Concepts, models and observations. Biological Journal of the Linnean Society, 42, 17-38. https://doi.org/10.1016/b978-0-12-284120-0.50005-x

Herrera, J. P., Duncan, N., Clare, E., Fenton, M. B., \& Simmons, N. (2018). Disassembly of fragmented bat communities in Orange Walk District, Belize. Acta Chiropterologica, 20, 147-159. https://doi. org/10.3161/15081109acc2018.20.1.011

Hoffmaster, E., Vonk, J., \& Mies, R. (2016). Education to action: Improving Public Perception of Bats. Animals, 6, 1-6. https://doi.org/10.3390/ ani6010006

Holdridge, L. R. (1967). Life zone ecology, Revised ed. San José, Costa Rica: Tropical Science Center.

Hutson, A. M., Mickleburgh, S. P., \& Racey, P. A. (2001). Microchiropteran bats: Global status survey and conservation action plan. Gland, Switzerland: IUCN/SSC Chiroptera Specialist Group.
Janzen, D. H. (1988). Management of habitat fragments in a tropical dry forest: Growth. Annals of the Missouri Botanical Garden, 75, 105-116. https://doi.org/10.2307/2399468

Kalko, E. K. V. (2004). Neotropical leaf-nosed bats (Phyllostomidae): 'Whispering' bats as candidates for acoustic surveys? In R. M. Brigham, E. K. V. Kalko, G. Jones, S. Parsons, \& H. J. G. A. Limpens (Eds.), Bat echolocation research: Tools, techniques and analysis (pp. 63-69). Austin, TX: Bat Conservation International.

Kunz, T. H., \& Kurta, A. (1988). Capture methods and holding devices. In T. H. Kunz (Ed.), Ecological and behavioral methods for the study of bats (pp. 1-28). Washington, DC: Smithsonian Institution Press.

Lacoeuilhe, A., Machon, N., Julien, J. F., \& Kerbiriou, C. (2016). Effects of hedgerows on bat and bush crickets at differential spatial scales. Acta Oecologica, 71, 61-72. https://doi.org/10.1016/j. actao.2016.01.009

Lagemann, J., \& Heuveldop, J. (1983). Characterization and evaluation of agroforestry systems: The case of Acosta-Puriscal, Costa Rica. Agroforestry Systems, 1, 101-115. https://doi.org/10.1007/bf005 96352

Lang, A. B., Kalko, E. K. V., Romer, H., Bockholdt, C., \& Dechman, D. K. N. (2006). Activity levels of bats and katydids in relation to the lunar cycle. Oecologica, 146, 659-666. https://doi.org/10.1007/ s00442-005-0131-3

Martínez-Fonseca, J. G., Chávez-Velásquez, M., Williams-Guillen, K., \& Chambers, C. L. (2019). Data from: Bats use live fences to move between tropical dry forest remnants. Dryad Digital Repository, https://doi.org/10.5061/dryad.44j0zpc99

Medina, A., Harvey, C., Merlo, D. S., Vilchez, S., \& Hernandez, B. (2007). Bat diversity and movement in an agricultural landscape in Matiguas, Nicaragua. Biotropica, 39, 120-128. https://doi. org/10.1111/j.1744-7429.2006.00240.x

Medina-Fitoria, A. (2014). Murciélagos de Nicaragua: Guía de campo. Managua, Nicaragua: Programa para la Conservación de los Murciélagos de Nicaragua (PCMN) y Ministerio del Ambiente y los Recursos Naturales (MARENA).

Medina-Fitoria, A., Saldaña, O., Martínez, J. G., Aguirre, Y., Silva, W., Chávez, M., \& Pérez, J. (2015). Nuevos reportes sobre los murciélagos (Mammalia: Chiroptera) de Nicaragua, América Central, con la adición de siete nuevos registros de especies. Mastozoología Neotropical, 22, 43-54.

Mello, M. A., Kalko, E. K. V., \& Silva, W. R. (2013). Effects of moonlight on the capturability of frugivorous phyllostomid bats (Chiroptera: Phyllostomindae) at different time scales. Zoologia (Curitiba), 30, 397-402. https://doi.org/10.1590/s1984-46702013000400005

Menezes-Jr, L. F., Duarte, A. C., Novaes, R. L. M., Façanha, A. C., Peracchi, A. L., Costa, L. C., ... Esbérard, C. E. L. (2008). Movement of Artibeus lituratus (Olfers, 1818) (Mammalia, Chiroptera) between island and continent on State of Rio de Janeiro, Brazil. Biota Neotropica, 8, 243245. https://doi.org/10.1590/s1676-06032008000200021

Meyer, C. F. J., \& Kalko, E. K. V. (2008). Assemblage-level responses of phyllostomid bats to tropical forest fragmentation: Land-bridge islands as a model system. Journal of Biogeography, 35, 1711-1726. https://doi.org/10.1111/j.1365-2699.2008.01916.x

Miles, L., Newton, A. C., DeFries, R. S., Ravilious, C., May, I., Blyth, S., ... Gordon, J. E. (2006). A global overview of the conservation status of tropical dry forests. Journal of Biogeography, 33, 491-505. https://doi. org/10.1111/j.1365-2699.2005.01424.x

Miller, B., \& Medina, A. (2008). Bauerus dubiaquercus. The IUCN Red List of Threatened Species 2008: e.T1789A7635960. Retrieve from http://dx.doi.org/10.2305/IUCN.UK.2008.RLTS.T1789A7635960. en.

Morrison, D. W. (1978). Lunar phobia in a neotropical fruit bat, Artibeus jamaicensis (Chiroptera: Phyllostomidae). Animal Behavior, 26, 852855. https://doi.org/10.1016/0003-3472(78)90151-3 
Morrison, D. W. (1980). Foraging and day-roosting dynamics of canopy fruit bats in Panama. Journal of Mammalogy, 61, 20-29. https://doi. org/10.2307/1379953

Naiman, R. J., Decamps, H., \& Pollock, M. (1993). The role of riparian corridors in maintaining regional biodiversity. Ecological Applications, 2, 209-212. https://doi.org/10.2307/1941822

Powell, A. H., \& Powell, G. V. N. (1987). Population dynamics of male euglossine bees in Amazonian forest fragments. Biotropica, 19, 176179. https://doi.org/10.2307/2388742

Reid, F. A. (2009). A field guide to the mammals of Central America and southeast Mexico, 2nd ed. Oxford, UK: Oxford University Press.

Rocha, R., Ferreira, D. F., Lopez-Baucells, A., Farneda, F. Z., Carreiras, J. M. B., Palmeirim, J. M., \& Meyer, C. F. J. (2017). Does sex matter? Gender-specific response to forest fragmentation in Neotropical bats. Biotropica, 49, 881-890. https://doi.org/10.1111/btp.12474

Rodhouse, T. J., Vierling, K. T., \& Irvine, K. M. (2011). A practical sampling design for acoustic surveys of bats. The Journal of Wildlife Management, 75, 1094-1102. https://doi.org/10.1002/jwmg.151

Rodriguez, B., \& Pineda, W. (2015). Ectophylla alba. The IUCN Red List of Threatened Species 2015: e.T7030A22027138. Retrieved from http://dx.doi.org/10.2305/IUCN.UK.2015-4.RLTS.T7030A2202 7138.en.

Sauer, J. D. (1979). Live fences in Costa Rican agriculture. Turrialba, 29, 225-261.

Saunders, D. A., \& de Ribeira, C. P. (1991). Values of corridors to avian populations in a fragmented landscape. In D. A. Saunders, \& R. J. Hobbs (Eds.), Nature conservation 2: The role of corridors (pp. 221240). Sydney, Australia: Surrey Beatty and Sons.

Schaub, A., \& Schnitzler, H. U. (2007). Flight and echolocation behavior of three vespertilionid bat species while commuting on flyways. Journa of Comparative Physiology, 193, 1185-1194. https://doi.org/10.1007/ s00359-007-0269-z

Schnitzler, H. U., Moss, C. F., \& Denzinger, A. (2003). From spatial orientation to food acquisition in echolocating bats. Trends in Ecology and Evolution, 18, 386-394. https://doi.org/10.1016/ s0169-5347(03)00185-x

Sesnie, S. E., Hagell, S., Otterstrom, S., Chambers, C. L., \& Dickson, B. J. (2008). SRTM-DEM and Landsat ETM? Data for mapping tropical dry forest cover and biodiversity assessment in Nicaragua. Revista Geografica Academica, 2, 53-65.
Sikes, R. S. \& the Animal Care and Use Committee of the American Society of Mammalogists (2016). Guidelines of the American Society of Mammologists for the use of wild mammals in research and education. Journal of Mammalogy, 97, 663-688. https://doi.org/10.1093/ jmammal/gyw078

Stockwell, E. F. (2001). Morphology and flight maneuverability in the new world leaf-nosed bats (Chiroptera: Phyllostomidae). Journal of Zoology, 254, 505-514. https://doi.org/10.1017/s095283690 1001005

Thies, W., Kalko, E. K. V., \& Schnitzler, H. U. (2006). Influence of environment and resource availability on activity patterns of Carollia castanea (Phyllostomidae) in Panama. Journal of Mammalogy, 87, 331-338. https://doi.org/10.1644/05-mamm-a-161r1.1

Toffoli, R. (2016). The importance of linear landscape elements for bats in a farmland area: The influence of height on activity. Journal of Landscape Ecology, 9, 49-62. https://doi.org/10.1515/ jlecol-2016-0004

Verboom, B., \& Huitema, H. (1997). The importance of linear landscape elements for the pipistrelle Pispistrellus pipestrellus and the serotine bat Eptesicus serotinus. Landscape Ecology, 12, 117-125.

Wilson, D. E., Cole, R., Nichols, J., Rudran, R., \& Foster, M. (1996). Measuring and monitoring biological diversity: standard methods for mammals. Washington, DC: Smithsonian Institution Press.

\section{SUPPORTING INFORMATION}

Additional supporting information may be found online in the Supporting Information section.

How to cite this article: Martínez-Fonseca JG, Chávez-

Velásquez M, Williams-Guillen K, Chambers CL. Bats use live fences to move between tropical dry forest remnants.

Biotropica. 2020;52:5-10. https://doi.org/10.1111/btp.12751 